\title{
MANGANESE ORE IN THE GOLD COAST
}

THE first recorded discovery of manganese ore in the Gold Coast Colony was made by Mr. A. E. Kitson, the Government geologist, in May, 1914, when he found occurrences of the ore at a point on the Sekondi-Kumasi Railway, about 33 miles from Sekondi, and 6 miles from Tarkwa.

Since then, other deposits have been found a few miles behind Dixcove, but, so far, prospecting work has shown them to be either too small, or carrying too high a percentage of oxides of iron, to be profitable.

Fragments of ore were first found a few yards from the railway on the northeast corner of the Dagwin Concession, held by the Fanti Consolidated Mines, Limited, and that company, which is now working the deposit, has traced the ore occurrence for about 21 miles in a northeasterly direction. Ore is found outcropping on or near the crest of a narrow ridge, which commences at the railway, and runs N.E. for about I miles, and is cut up into three sections by small necks or depressions. There is a second and parallel ridge, about $\frac{f}{\mathrm{~g}}$ mile W. of the first one, which commences at about it miles from the railway, and runs for about It miles. The two ridges, therefore, overlap for half-a-mile or so.

The importance of the discovery does not appear to have been recognised for some time, and, although Mr. H. Kilburn Scott was then sent out by the Grovernment to make a further examination, the whole matter was kept an official secret until May, 1916, when it was found that the ore deposit was on a concession held for some years by a private company. The Fanti Consolidated Mines were then instructed that manganese was urgently needed for munitions purposes, and they were required to start production immediately. Fortunately, the company was closely 
associated with Abontiakun, a working gold mine at Tarkwa, only 6 miles away, and was, therefore, in a position to arrange with Abontiakun for the assistance of its staff of officials, who were on the spot, as well as the

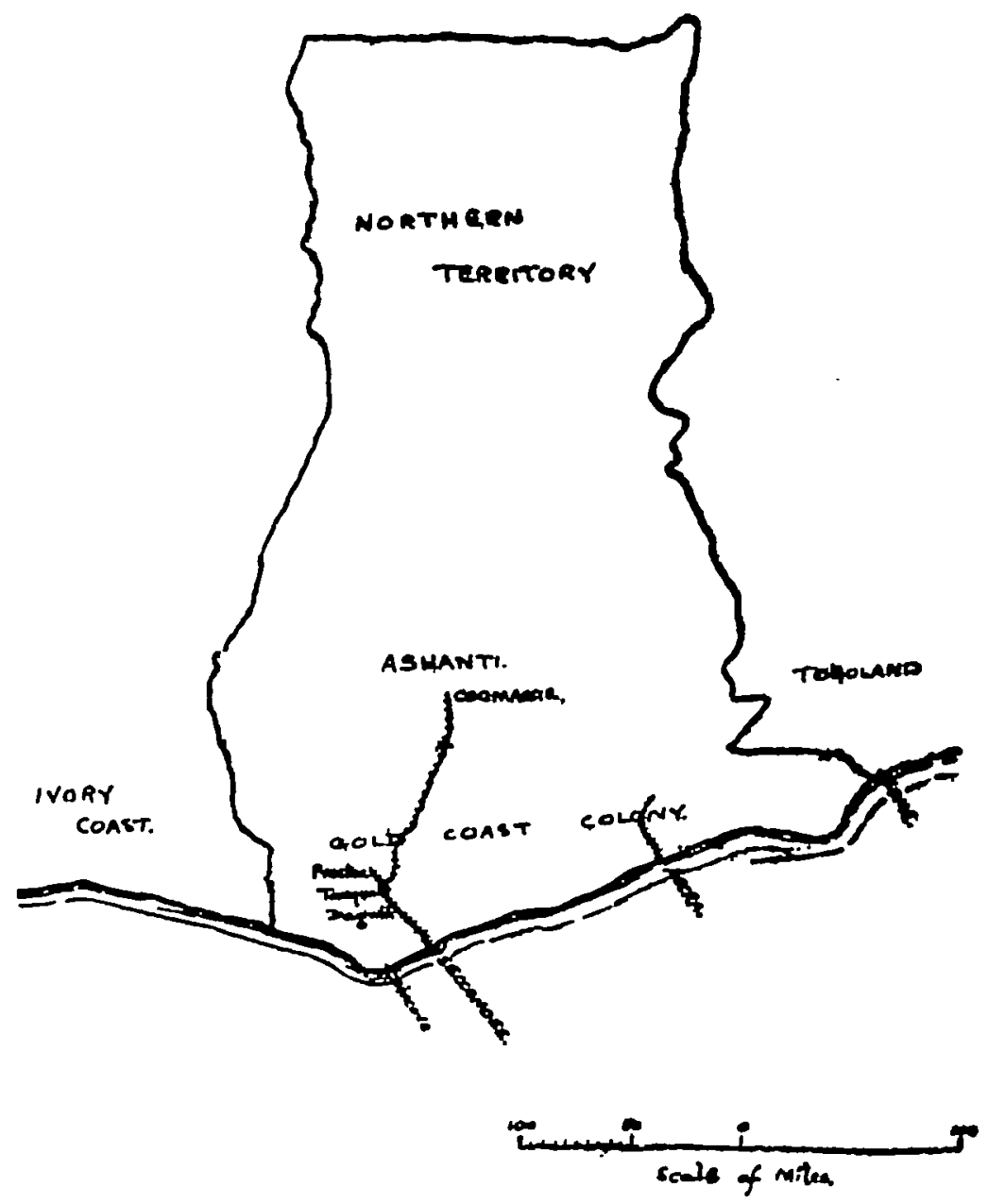

necessary mining supplies and well-equipped workshops in full working order.

This fact undoubtedly made it possible to ship ore several months sooner than could otherwise have been done-the first shipment, 174 tons, was made in September, 1916-but 
if the available information had been made public, it would have been possible to send home this much-needed material still sooner. In this connection it is interesting to compare the attitude adopted with that of the United States Government in its publication of the Bulletins and Reports of the Bureau of Mines.

The early work was carried on under considerable diffculty, as the ground was covered either with heavy timber, or, what was still worse from the prospecting point of view, with secondary growth on ground which had been cleared by natives for their farms, and then abandoned.

Owing to war requirements, it was necessary to commence production, then to lay out the work and organise the labour as it came in, and, finally, to clear the ground to get some idea of the character and size of the deposit, and the best way of working it. Under the circumstances, it was not possible to do anything else, but the method of working, which was adopted with very little knowledge of the conditions, is likely to lead to some difficulties in the future.

The available supply of native labour was also insufficient, but this difficulty was met by the Governor, Sir Hugh Clifford, who from the beginning took a keen interest in the work, and on whose instructions labourers were recruited both in the Northern Territories and in that part of Togoland which had come under his administration. He also caused two sidings to be put in from the Government railway line : these are about half-a-mile and a mile-and-three-quarters long, respectively, and proved useful for the early shipment of large tonnages of ore.

No outcrops of unaltered rocks are found near the ore deposit, and it is, therefore, somewhat difficult to arrive at a coriclusion as to its genesis. It, however, seems to have been derived from the intrusion of a mass of quartz porphyry into the phyllites, about 2 miles to the east.

Silica and manganese were both probably introduced into the porphyry and the phyllites-into the latter through fissures or zones of fracture-by thermal waters. Subsequently, by a combination of tropical conditions and the action of surface waters, manganese and iron have been 


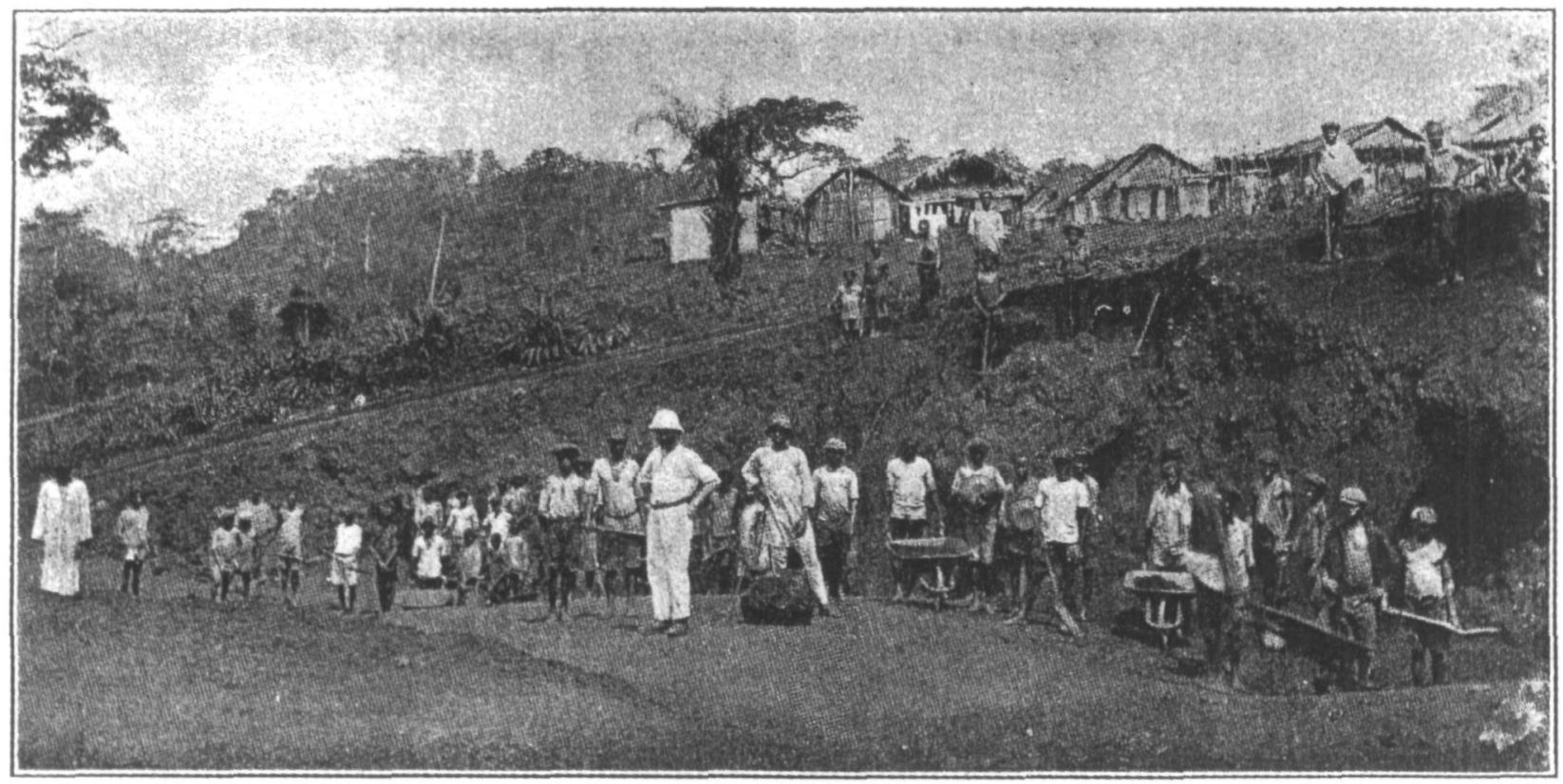

DAGWIN ExTENSTON.

Removing overburden containing manganese boulders.

View taken just above inain ore line and a few yards north of boundary between Dagrin and Dappin Extension.

European-R J. CRAZE- standing on refume which has been thrown back after recovery of manganese boulders. Bnuldera shown in situ on right. fragments to which reference has so often been made 

dissolved out as carbonates, and re-precipitated again as hydrated oxides.

In places, the percentage of manganese falls to 10 or 15 , and that of the iron rises to 30 or 40 , which makes it a manganiferous iron ore; under present conditions, it is not considered to be a commercial article.

Bands of quartz are sometimes found running through the ore, but they are more noticeable in the ore exposed in the tunnels.

There appear to be a series of ore bodies, itregular in size and shape, which outcrop along the ridges running N.E. from the 33-mile post on the railway; the longer axis of each ore body also lies in a N.E., S.W. line. The ore bodies do not appear to be actually connected with each other.

The largest one on which any work has yet been done has been prospected by a tunnel put in at about 300 feet below the outcrop; the length of the ore body is about 250 feet, its maximum width about 120 feet, with an average of 40 to 50 feet.

There is ore of shipping grade still below the level of the floor of the tunnel, and the depth to which it continues has not been proved.

The walls of the ore body are phyllites, and the junction between the two is quite clear and distinct, although the manganese content decreases rapidly in the few feet before the wall is reached.

Besides the ore body now described, there are two or three others, on which but little work has been done, but which probably are as large, if not larger, than the first one.

In smaller ore bodies it has been found that the manganese content decreases in depth, and there is a gradual passage into light-coloured lithomarges, which are phyllites chemically altered by the leaching out of various constituents.

In addition, the flanks of the ridges are covered with a "detrital" layer made up of ore fragments or nodules embedded in a reddish clay. These fragments vary in size from that of a pea up to boulders weighing 10 or 12 tons.

Probably part of the material called "detrital" ore has 
actually been formed in situ, from manganese-bearing solutions which have come from higher levels, suitable small grains acting as nuclei on which the nodules found embedded in the clay have been built up.

The ore-bearing layer, which rests on lithomarges, varies in thickness from a few inches to 15 or 18 feet, and the contact between the ore and the underlying clay is very wavy and irregular. In places there is also a layer of clean red sand overlying the detrital ore deposit : this sand is anything from a few inches up to to feet in thickness.

The ore is principally psilomelane (a hydrous oxide of manganese with baryta), while less frequently pyrolusite (the dioxide), manganite (hydrous oxide), and rhodonite (silicate) are also found.

$U_{p}$ to the present, all the ore shipped has been recovered from the "detrital layer"; but plans have been got out for working the massive deposits.

The system of working has been to commence on the lower slopes of the hill, as low down as possible, to take off the sand overburden for a distance of 20 feet or so up the hill-the sand being trammed away to beyond the limits of the ore deposit-then to break down the exposed detrital layer either with pick and shovel, or by blasting where necessary, and sort out the ore, which is then stacked ready for tramming to the railway siding. The residual clay is trammed away to the waste dump.

From September, 1916, to April, 1920, inclusive, 108,000 tons of ore have been shipped; the largest proportion has come to the United Kingdom, but other cargoes have gone to the United States and to France.

A few hundred tons of nearly pure pyrolusite have also been shipped. During the war, it was used for making chlorine, and at the present time there is a considerable demand for it in the manufacture of electric dry batteries, or for de-colourising glass; for either purpose it has to be very pure and free of iron, and naturally commands a higher price than the ordinary ore as used for steel alloys.

The ordinary run of ore shipped is of first grade quality; the average analysis is 50 to 5 I per cent. manganese, 4.3 per 


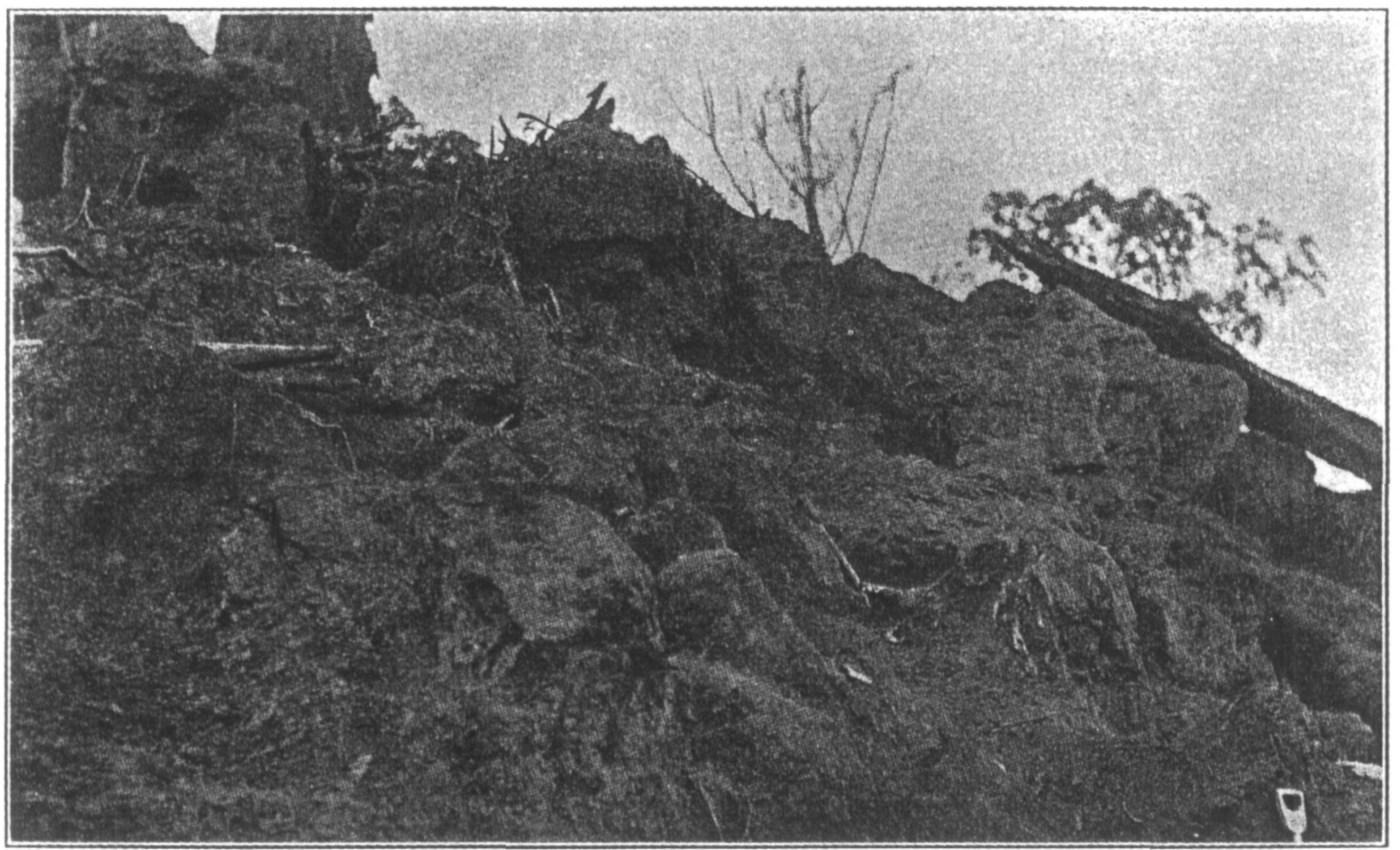

Manganese Workings: Dagwin Extengion, August 30, igio.

Manganese orc nutcrop uncovered for drilling (at W. end of trencli on crest of hill).

[T. $\sec A \cdot 38$ 

cent. iron, 7.0 per cent. insoluble matter (principally silica), and 0. I per cent. phosphorus. These values show the ore to be of high grade, and well above the limits required for first-class ore, which now are 49 per cent. and upwards of manganese, not more than 8 per cent. silica, or 0.25 per cent. phosphorus; it finds a ready market for the manufacture of high-grade ferro-manganese, an iron manganese alloy containing up to 80 per cent. manganese.

The pre-war price of the ore at a U.K. port was about IId. per unit (a unit equals each I per cent. manganese, so that an ore containing 49 per cent. manganese is worth $49 \times 11=445$. IId. per ton). At present, May, 1920, the price is abnormally high, owing to shortage of stocks in the country.

The world's production in 1913 was in the neighbourhood of 2,300,000 tons, together with approximatedy a further $1, \infty 00, \infty 00$ tons of manganiferous iron ores, containing up to 30 per cent. manganese and from 30 to 60 per cent. of iron, the manganese and iron together being not less than 50 per cent.

During the war, the Russian production ( $1,300,000$ tons in I913) ceased, and it has been replaced by a largelyincreased output from Brazil, together with an increase in the manganiferous iron ore worked in the United States, which in 1917 amounted to $1 \frac{7}{2}$ million tons of under 40 per cent. ore.

Production was much stimulated by the war, and more lower-grade ores were used, especially in the United States, than is likely to be the case in the future.

It may, therefore, be expected that the use of low grade ore will be discontinued, as supplies of the high grade (over 49 per cent.) material become available.

The principal users of manganese ores are the United States, Germany, and the United Kingdom, and until Russia again becomes a producer, the Gold Coast Colony is more favourably situated geographically than any other place, to meet the demands of the principal consumers.

The company now working at Dagwin has under consideration plans for a plant capable of producing 200,000 
tons a year, but in order to carry these out it will be necessary for radical improvements to be made in the methods of dealing with the ore after it has been put on rail. These are entirely in the hands of the Government, who own both the railway and the port of Sekondi.

Transport facilities to Sekondi are wholly inadequate, even for the present rate of production, and at the port itself the system of transport to the steamer is most primitive.

Railage rates, including harbour dues, are also very high; at the present time, they amount together to $8 s$. $6 \mathrm{~d}$. per ton, or 3 d. per ton mile for the 34 miles hauled. This charge is for material hauled in bulk, and by the train load, and compares most unfavourably with the rates charged elsewhere-.$- g$. , for the transport of the Indian ores which have to be hauled for distances varying from 270 to 780 miles.

For quick despatch of steamers, storage bins and loading facilities at Sekondi are necessary, and in 1917 the company made proposals to the Government that it should put up bins for the purpose. These proposals were not accepted on the ground that space at Sekondi was restricted, and therefore no private corporation could be allowed to construct a jetty there. The subject was then having the consideration of the Government, and so far as is known, it is still having consideration.

It is much to be hoped that a decision will be come to without further undue delay, as meanwhile an opportunity for the full development of a valuable asset of both the Colony and the Empire is being lost.

S. H. FORD. 